\title{
Digital Parenting: Bagaimana Mencegah Kecanduan Gadget. \\ DIGITAL PARENTING: BAGAIMANA MENCEGAH KECANDUAN GADGET PADA ANAK
}

\author{
${ }^{a}$ Ahmad Sudi Pratikno ${ }^{1}$ \\ ${ }^{a}$ Program Studi PGMI, Institut Agama Islam Al-Falah As-Sunniyah, Kencong, Jember, Jawa
}

Timur

${ }^{\mathrm{b}}$ Sumantri

${ }^{\mathrm{b}}$ Kepala Sekolah SDN Gadingrejo 03, Umbulsari, Jember, Jawa Timur

Email ${ }^{1}$ ahmadsudi.ibnsuman@gmail.com

\begin{abstract}
As a big country, Indonesia should be able to foster the youth, especially in shaping good behavior (character). Good behavior comes from good parenting. However, the current level of adoption of gadgets is increasingly worrying, subsequently concrete steps are needed to implement parenting in the digital age in order to avoid gadget addiction of children and good attitude and mental shape are formed within the child. Some efforts that can be done are by utilizing the features provided by digital companies and the iOS and Android operating systems, implementing classical conditioning, as well as making agreements between children and parents regarding the duration of gadget usage.
\end{abstract}

Keywords: digital parenting, gadget addiction, children

Abstrak

Sebagai negara yang majemuk, Indonesia harus mampu untuk membina generasi muda terutama dalam membentuk perilaku yang baik (karakter). Perilaku yang baik berasal dari pola asuh orangtua yang baik. Namun demikian, tingkat adopsi gadget saat ini semakin mengkahwatirkan, sehingga perlu langkah-langkah konkret untuk menerapkan pola asuh di era digital, agar anak-anak terhindar dari kencanduan gadget serta terbentuk sikap dan mental yang baik di dalam diri anak. Beberapa upaya yang dapat dilakukan adalah dengan memanfaatkan fitur yang disediakan oleh perusahaan digital dan sistem operasi iOS dan android, menerapkan classical conditioning, serta membuat perjanjian antara anak dengan orangtua perihal durasi pemakaian gadget.

Kata Kunci: digital parenting, kecanduan gadget, anak

\section{Pendahuluan}

Pola asuh yang terus berkembang dari waktu ke waktu menjadikan dunia parenting semakin kompleks. Hal ini tidak tertutup pada dunia anak yang secara harfiah melibatkan peran orang tua secara utuh dalam pengasuhan. Pola asuh orang tua kepada anak memberikan dampak yang luar biasa terhadap perkembangan psikologi anak. Pola asuh dapat membangkitkan ingatan secara emosional ${ }^{12345}$. Pengetahuan tentang proses emosional dalam pola asuh, termasuk

${ }^{1}$ Cole, P. M., LeDonne, E. N., \& Tan, P. Z. A longitudinal examination of maternal emotions in relation to young children's developing self-regulation. Parenting, (2013), 13(2), hlm. 113-132.

2 Denham, S. A. Maternal emotional responsiveness and toddlers' social-emotional competence. Journal of Child Psychology and Psychiatry, (1993). 34(5), hlm. 715-728. 
penilaian, sikap, dan aturan adalah hal yang penting dalam memahami sikap dalam pola asuh, demikian juga untuk mengenalkan perkembangan anak yang sehat ${ }^{6}$. Sejalan dengan pendapat tersebut, Measelle \& Ablow ${ }^{7}$ menambahkan bahwa pola asuh memiliki peran penting terutama oleh orangtua kepada anak. Seperti contoh pada seorang bayi, mereka akan merasa aman pada saat mendapatkan pola asuh yang hangat dan responsif, terutama saat-saat situasi sulit. Pola asuh pada era digital ini menuntut orang tua untuk mengawasi anaknya dalam menggunakan media elektronik. Sebuah survei di 25 negara di Eropa ditemukan bahwa 87\% anak-anak memiliki akses internet di rumah, dan 49\% memiliki akses internet di kamar mereka ${ }^{8}$.

Selain itu, survei dari Eurobarometer pada tahun 2008, seperti survei-survei lainnya, menunjukkan bahwa secara keseluruhan perhatian orang tua kepada keamanan online anakanak mereka tinggi, hal ini tampaknya akan mendorong munculnya desain praktik untuk membuat pengguna internet lebih aman terutama untuk anak-anak ${ }^{9}$. Temuan tersebut juga dikuatkan dengan riset yang dilakukan oleh Northwestern University di Eropa, ditemukan bahwa orangtua dari anak yang berusia $0-8$ tahun tidak begitu perhatian terhadap media yang digunakan anaknya. Hanya sepertiga (30\%) dari orang tua yang mengatakan mereka "sangat" (13\%) atau "kadang-kadang" (17) peduli terhadap penggunaan media dan teknologi pada anak mereka, sedangkan 55\% mereka mengatakan "tidak terlalu" (31\%) atau " tidak sama sekali" $(24 \%)$ peduli ${ }^{10}$.

Berbeda dengan kondisi yang ada di Eropa, di Indonesia rata-rata anak menghabiskan waktunya sehari-hari selama lebih dari satu jam untuk menonton televisi (54,4\%), memutar video (30\%), membaca buku (8,2\%), mengoperasikan komputer (32,5\%), dan 67,3\% bermain game elektro-nik ${ }^{11}$. Oleh sebab itu, proteksi orangtua kepada anak harus kuat dan disiplin, sehingga perilaku anak sehari-hari dapat dikontrol dengan baik terutama saat menggunakan media elektronik seperti internet.

Pada penelitian-penelitian yang telah dilakukan, pola asuh yang telah diteliti hanya di beberapa kondisi, antara lain pada saat makan siang bersama keluarga ${ }^{121314151617}$, saat

\footnotetext{
${ }^{3}$ Huang, K.-Y., Teti, D. M., Caughy, M. O., Feldstein, S., \& Genevro, J. Mother-child conflict interaction in the toddler years: Behavior patterns and correlates. Journal of Child and Family Studies, (2007), 16(2), hlm. 219-241.

${ }^{4}$ Martin, S. E., Clements, M. L., \& Crnic, K. A. Maternal emotions during mother-toddler interaction: parenting in affective context. Parenting, (2002), 2(2), hlm. 105-126.

${ }^{5}$ Hajal, N. J., Cole, P. M., \& Teti, D. M. Maternal responses to infant distress: linkages between specific emotions and neurophysiological processes. Parenting, (2017), 17(3), hlm. 200-224.

${ }^{6}$ Ibid

${ }^{7}$ Measelle, R. J., \& Ablow C. J. Contributions of early adversity to pro-inflammatory phenotype in infancy: the buffer provided by attachment security. Attachment \& Human Development. (2017).

${ }^{8}$ Livingstone S, Haddon L, Görzig A, et al. EU kids online final report. LSE, London: EU Kids Online. (2011).

${ }^{9}$ Livingstone, S., \& Haddon, L. EU kids online: Final report. LSE, London: EU Kids Online. (2009).

${ }^{10}$ Center on Media and Human Development. Parenting in the age of digital technology: A national survey (revised). School of Communication, Northwestern University. (2014).

${ }^{11}$ Hendriyani, Hollander, E., d'Haenes, L., Beentjes, J. Views on children's media use in Indonesia: Parents, children, and teachers. International Communication Gazette. (2014) 76(4-5), hlm.322-339.

12 Radesky, J., Miller, A. L., Rosenblum, K. L., Appugliese, D., Kaciroti, N., \& Lumeng, J. C. Maternal mobile device use during a structured parent child interaction task. Academic Pediatrics, (2014), 15(2), hlm.238-244.

108 | Jurnal Auladuna
} 
Digital Parenting: Bagaimana Mencegah Kecanduan Gadget........... memberikan makan anak-anak atau sedang bermain ${ }^{181920}$ di tempat umum ${ }^{2122}$, saat liburan ${ }^{23}$, dan saat berada di rumah ${ }^{24}$. Begitu juga dengan pola asuh dalam penelitian lainnya yang hanya berupa sebuah aturan mengikat dan membatasi anak dengan berbagai peraturan yang dibuat antara anak dan orangtua ${ }^{25}$. Dalam teori classical conditioning, Schunk ${ }^{26}$ berpendapat bahwa perilaku anak dapat dibentuk melaluii pengkondisian lingkungan. Hal ini yang masih belum tampak terhadap penelitian-penelitian yang telah dilakukan sebelumnya terutama dalam pembentukan watak dan perilaku yang baik pada anak. Penelitian ini mengantisipasi kecanduan gadget pada anak dari sisi perkembangan kecerdasan spiritual anak dengan memaksimalkan penanama karakter religius melalui suatu pembiasaan dalam lingkungan keluarga serta awal pembentukan perilaku yang dapat dijadikan sebagai salah satu upaya pencegahan gadget addiction.

Penelitian ini meninjau dari sisi penerapan karakter religius yang ada pada 18 karakter menurut Kemendikbud. Pola penerapan kebiasaan pada diri anak dengan menerapkan kegiatan Gerakan Magrib Mengaji ini dapat melalui beberapa macam kegiatan, misalnya dalam kegiatan mengaji di pesantren, musholla, masjid maupun kegiatan mandiri mengaji alquran dengan didampingi oleh guru maupun orang tua siswa. Peran orang tua sangat pentin guna tercapainya tujuan kegiatan tersebut. Selain itu, orang tua juga dapat membiasakan dalam diri sendiri untuk mengendalikan perilaku pemakaian gadget terlalu sering.

13 Hiniker, A., Schoenebeck, S. Y., \& Kientz, J. A. Not at the dinner table: Parents' and children's perspectives on family technology rules. In Proceedings of the19th ACM conference on computer-supported cooperative work \& social computing (2016), hlm.1376-1389.

${ }_{14}$ Moser, C., Schoenebeck, S. Y., \& Reinecke, K. Technology at the table: Attitudes about mobile phone use at mealtimes. In Proceedings of the 2016 conference on human factors in computer systems, (2016), hlm. 1881-1892

15 Oduor, E., Neustaedter, C., Odom, W., Tang, A., Moallem, N., Tory, M., et al. The frustrations and benefits of mobile device usage in the home when copresent with family members. In Proceedings of the annual designing interactive systems conference, (2016), hlm.1-13.

16 Radesky, J. S., Kistin, C. J., Zuckerman, B., Nitzberg, K., Gross, J., Kaplan-Sanoff, M., et al. Patterns of mobile device use by caregivers and children during meals in fast food restaurants. Pediatrics, (2014), 133(4), hlm.e843e-e850.

17 Kildare, C. A., \& Middlemiss, W. Impact of parents mobile device use on parent-child interaction: A literature review. Computers in Human Behavior, (2017)75, hlm.579-593.

18 Ante-Contreras, D. Distracted parenting: How social media affects parent-child attachment (Unpublished master's thesis). San Bernardino, CA: California State University. (2016).

19 Golen, R. B., \& Ventura, A. K. Mindless feeding. Is maternal distraction during bottle-feeding associated with overfeeding? Appetite, (2015), 91, hlm.385-392.

20 McDaniel, B. T., \& Coyne, S. M. (2016). Technology interference in the parenting of young children: Implications for mothers' perceptions of coparenting. The Social Science Journal, (2016), 53(4), hlm.435-443.

${ }^{21}$ Hiniker, A., Schoenebeck, S. Y., \& Kientz, J. A. op cit. hlm.1376-1389.

22 Kushlev, K. (2015). Digitally connected, socially disconnected: Can smartphones compromise the benefits of interacting with others? (Unpublished doctoral dissertation). Vancouver, Canada: The University of British Columbia. (2015).

${ }^{23}$ Kildare, C. A., \& Middlemiss, W. op cit. hlm.579-593

24 Blackman, A. (2015). Screen time for parents and caregivers: Parental screen distraction and parenting perceptions and beliefs (Unpublished doctoral dissertation). New York, NY: Pace University. (2015).

25 Álvarez, M., Torres, A., Rodríguez, E., Padilla, S., Rodrigo, J. M., (2013). Attitudes and parenting dimensions in parents' regulation of Internet use by primary and secondary school children. Computer \& Education. 67(2013), hlm.69-78.

${ }^{26}$ Schunk, D. H. Learning Theories. Pustaka Pelajar: Yogyakarta. (2012).

109 | Jurnal Auladuna 
Pola perilaku mengasuh anak dan kualitas interaksi orang tua terhadap anak secara kritis akan membentuk perkembangan dalam diri anak ${ }^{27}$. Apabila dikaitkan dengan perkembangan IPTEK saat ini, maka pola asuh preventif sangat diperlukan mengingat ekspansi dari gadget sudah luar biasa. Oleh sebab itu, penelitian ini akan meneliti tentang beberapa upaya yang dapat dilakukan untuk mencegah kecanduan gadget di kalangan siswa sekolah dasar.

\section{Kajian Teori}

\section{Digital Parenting (Pola Asuh di Era Digital)}

Sebelum menganalisis tentang bagaimana menerapkan pola asuh dalam mencegah kecanduan gadget pada anak, maka terlebih dahulu dibahas mengenai apakah definisi dari dan digital dan pola asuh (parenting). Digital is connected with the use of computer technology, especially the internet $^{28}$. Digital merupakan sebuah langkah terhubung dengan menafaatkan komputer khusunya melalui penggunaan internet. Pola asuh (parenting) menurut kamus oxford berasal dari kata dasar parent yang berarti orang tua. Sedangkan Parenting yakni the process of caring for your child or children $^{29}$. Parenting adalah proses dari kepedulian terhadap anak-anak. Sejalan dengan itu, Borstein $^{30}$ menyatakan bahwa pengasuhan (parenting) adalah perpaduan altruisme, prososial, pengabdian, dan selektivitas yang halus, ditandai dengan tuntutan, kriteria perubahan dan ambigu yang terus-menerus menantang, dan evaluasi yang terlalu sering dilakukan. Parenting diakui sebagai kunci pencegahan kejahatan dan kegagalan pendidikan ${ }^{31}$, di samping itu juga terdapat semakin banyak bukti di tingkat internasional bahwa program pengasuhan dapat berjalan efektif dan hemat biaya dalam membantu anak-anak dengan memberikan perilaku menantang ${ }^{32}$. Para orangtua melaporkan bahwa menghabiskan waktu bersama anak-anak mereka, terutama saat rekreasi atau sedang di penitipan anak merupakan bagian dari kegiatan mereka yang paling menyenangkan ${ }^{33}$.

Dalam pandangan Islam, pola asuh sangat ditekankan karena kasih sayang orangtua kepada anak itu penting. Seperti hadits dari Rosululloh SAW. berikut ini.

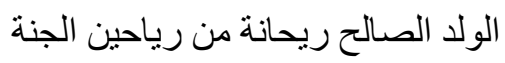

Artinya: Anak yang sholih adalah bunga surga. (al-Hadits)

27 Fay-Stammbach, T., Hawes, D. J., \& Meredith, P. Parenting influences on executive function in early childhood: A review. Child Development Perspectives, (2014), 8(4), hlm.258-264.

28 Oxford Learner's Dictionaries, https://www.oxfordlearnersdictionaries.com/ definition/english/digital 1?q=Digital

29 Oxford Learner's Dictionaries, https://www.oxfordlearnersdictionaries.com/ definitions/english/parenting? q= Parenting

${ }_{30}$ Bornstein, M. H. (2016). Determinants of parenting. Developmental Psychopathology, Third Edition, John Wiley \& Sons. (2016).

31 Bloomfield, L., \& Kendall, S. Parenting self-efficacy, parenting stress and child behavior before and after a parenting programme. Primary health care research \& development, (2012), 13, hlm.364-372.

32 Ibid

${ }^{33}$ Krueger, A., Kahneman, D., Schkade, D., Schwarz, N., \& Stone, A. National time accounting: The currency of life. In A. Krueger (Ed.), National time accounting and subjective well-being. Chicago, IL: University of Chicago Press. (2009). hlm.9-84

110 | Jurnal Auladuna 
Digital Parenting: Bagaimana Mencegah Kecanduan Gadget

Membentuk akhlak yang baik kepada anak diibaratkan seperti mencari sebuah Bunga di taman surga, oleh sebab itu, para orangtua perlu memperhatikan pola asuh serta perkembangan fisik dan psikis anak terutama yang berhubungan dengan pembentukan tingkah laku anak.

Pola asuh dalam era digital bergeser dari paradigma lama bahwa anak hanya belajar dari lingkungan dan orang tua (Bornstein, 2016). Apabila dikaitkan dengan kondisi saat ini, anak juga memiliki kecenderungan untuk mengakses media (televisi, internet, gadget, dll.) dalam rangka mencari tahu informasi dan menuruti rasa keingintahuannya. Pola asuh yang memberikan kelembutan, ikatan bathin, dan kasih sayang akan memberikan rasa aman, nyaman, dan tenang dalam diri anak, sehingga hal ini akan membantu dalam mengurangi rasa candu anak terhadap gadget. Oleh karena itu, penelitian ini berangkat pada kondisi nyata di lapangan serta bertujuan untuk mencegah kecanduan gadget terutama pada siswa SD. Melalui beberapa langkah preventif yang diupayakan, maka diharapkan dapat memacu siswa dalam berperilaku sopan, efektif, serta semangat dalam belajar dan mengaji.

\section{Metode Penelitian}

Penelitian ini dilakukan menggunakan metode kualitatif deskriptif. Qualitative descriptive is a widely cited research tradition and has been identified as important and appropriate for research questions focused on discovering the who, what, and where of events or experiences and gaining insights from informants regarding a poorly understood phenomenon ${ }^{3435}$. Penelitian deskriptif kualitatif adalah penelitian yang diidentifikasi sebagai penelitian yang penting dan sesuai terhadap beberapa rumusan masalah yang berfokus pada penggalian siapa, apa dan dimana dari sebuah kejadian atau pengalaman, serta memperoleh keingintahuan dari beberapa informan mengenai fenomena yang sulit dipahami. Metode penelitian kualitatif deskriptif memberikan gambaran tentang suatu gagasan atau fenomenologi yang terjadi di masyarakat. Sumber data yang digunakan yakni: i) koleksi literatur dari media elektronik berupa jurnal, buku, serta artikel akademik lainnya; ii) observasi terhadap beberapa siswa sekolah dasar. Teknik analisis data yang digunakan adalah analisis deskriptif.

Dalam penelitian ini, peneliti menilai keberhasilan dari studi ini akan tampak pada beberapa indikator: 1) perubahan perilaku anak terhadap penggunaan gadget, 2) penurunan intensitas penggunaan gadget pada anak; 3) terdapat peningkatan pembacaan alquran secara tartil dalam diri anak; 4) peningkatan minat mengaji anak; serta 5) kemampuan kognitif anak dalam memahami materi dan ilmu pengetahuan.

\section{Hasil dan Pembahasan}

\section{Upaya dalam Mencegah Adiksi Gadget}

Digital parenting atau pola asuh di era digital sangat penting dipahami dan dilakukan tidak oleh orang tua namun juga bagi guru. Perkembangan yang begitu masif membuat para siswa

\footnotetext{
${ }^{34}$ Neergaard MA, Olesen F, Andersen RS, \& Sondergaard J. Qualitative description - the poor cousin of health research?. BMC Medical Research Methodology. (2009), 9(52).

${ }^{35}$ Sullivan-Bolyai S, Bova C, Harper D. Developing and refining interventions in persons with health disparities: the use of qualitative description. Nursing Outlook. (2005), 53(3), hlm.127-133

111 | Jurnal Auladuna
} 
yang notabene masih berada di tahap operasional konkret mampu menjelajah dan menelaah berbagai informasi lebih cepat dari guru mereka yang ada di sekolah bahkan dari orangtua mereka di rumah. Kecepatan dan kemudahan dalam mengakses informasi dan ilmu pengetahuan selayaknya harus dikawal dan diamati agar tidak terjadi penyelewengan, pembelokan, dan pelanggaran dalam penggunaan internet terutama yang berkaitan dengan adiksi gadget. Untuk mengatasi adiksi gadget dan upaya pencegahannya, guru maupun orang tua dapat menerapkan beberapa langkah sebagai berikut.

\section{GMM (Gerakan Maghrib Mengaji)}

GMM telah digagas oleh Kementerian Agama pada tahun 2013, namun tingkat implementasinya dirasa masih rendah. Pada tahun 2020 diharapkan GMM dapat ditingkatkan lagi agar memberikan pengaruh positif bagi generasi muda Indonesia, mengingat perilaku mereka terhadap penggunaan gadget saat ini yang mengkhawatirkan. Perilaku penggunaan gadget pada siswa SD, dapat dilihat dengan mengetahui durasi pemakaiannya. Para orangtua tidak hanya membatasi penggunaan gadget pada anak namun juga harus mengontrol apa yang disuguhkan (konten) kepada anak. Peran serta orangtua sangat penting di sini karena keluarga adalah lingkungan pertama bagi anak dan hal inilah yang seharusnya dimaksimalkan dalam pembentukan karakter dalam diri anak.

Gerakan Maghrib Mengaji (GMM) merupakan sebuah pembiasaan yang dilakukan oleh orang tua, guru TPA, kyai, maupun ustadz dan ustadzah untuk mendidik siswa (santri) setelah sholat Maghrib. Kegiatan ini umum dan telah banyak dilakukan di Pesantren, Masjid dan Musholla yang ada di desa maupun di kota. Gerakan maghrib mengaji dapat diisi dengan membaca alquran, mempelajari kitab kuning, ilmu tajwid, akhlak, serta beberapa aktivitas lainnya. Kegiatan ini tidak hanya berlangsung di Masjid, Musholla atau di Pesantren, namun juga dapat dilakukan di rumah masing-masing. Mengingat sekarang ini masih terjadi wabah virus corona di Indonesia, sehingga mengharuskan masyarakat untuk tetap tanggal dan beraktivitas di dalam rumah. Langkah pencegahan oleh orangtua maupun guru kepada anak terhadap kecanduan gadget yakni melalui GMM yang berlangsung selama 30-45 menit setiap selesai sholat maghrib hingga menjelang waktu sholat isya' tiba. Gerakan maghrib mengaji dengan durasi 30-45 menit dapat berlangsung minimal selama satu tahun. Hal tersebut dilakukan agar pembentukan perilaku dalam diri anak dapat terbentuk maksimal. Suatu proses pembiasaan sikap membutuhkan proses yang lama dan tentu membutuhkan kesabaran serta ketelatenan dalam melaksanakannya.

Upaya dalam membentuk karakter religius dalam diri anak melalui gerakan maghrib mengaji adalah upaya preventif yang dianggap realistis untuk dilakukan. Apabila karakter religius ini terbentuk dalam diri anak, maka diharapkan dapat mencegah anak untuk tidak kecanduan gadget maupun mengurangi rasa candu anak terhadap bermain game online dan beberapa kegiatan lainnya yang tidak bermanfaat. Berikut beberapa foto kegiatan gerakan maghrib mengaji yang dilaksanakan di Musholla dan Masjid.

112 | Jurnal Auladuna 


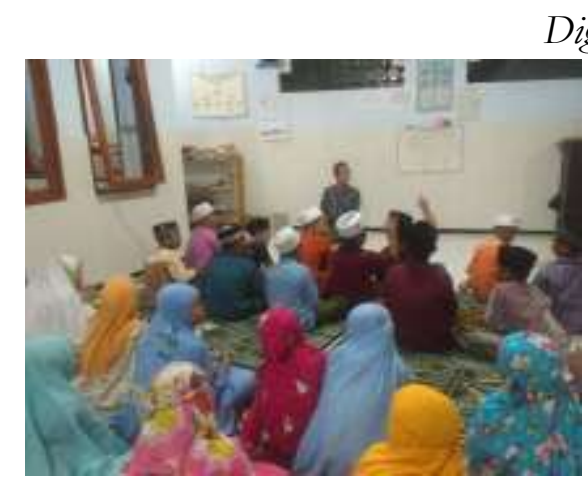

Gambar 1. GMM di Musholla

Digital Parenting: Bagaimana Mencegah Kecanduan Gadget...........

\section{Classical Conditioning (Pengkondisian Klasik)}

Pengkondisian klasik adalah tipe pembelajaran di mana suatu organisme belajar untuk mengaitkan atau mengasosiasikan stimulus. Dalam pengkondisian klasik, stimulus netral (seperti melihat seseorang) diasosiasikan dengan stimulus yang bermakna (seperti makanan) dan menimbulkan kapasitas untuk mengeluarkan respon yang sama ${ }^{37}$.

Penelitian tentang pengkondisian klasik dimulai pada awal abad 1849-1936 saat Ivan Pavlov, seorang ahli psikologi Rusia meneliti proses pencernaan anjing. Menurut Pavlov ${ }^{38}$ proses yang secara berulang-ulang menghubungkan stimulus netral atau sering disebut Unconditioned Stimulus (UCS). Melalui penerapan stimulus tanpa pengkondisian diharapkan mampu membangkitkan tanggapan pengkondisian (CR). Stimulus tak bersyarat dalam penelitian Pavlov adalah makanan yang kemudian menghasilkan tanggapan/respon tanpa pengkondisian atau Unconditioned Response (UCR) yaitu merupakan perilaku yang otomatis didorong oleh stimulus, dalam penelitiannya Pavlov berupa air liur. Selanjutnya stimulus bersyarat atau Conditioned Stimulus (CS) adalah stimulus yang secara alami tidak mempunyai dampak pada tanggapan atau respon tertentu, misalnya bunyi bel, tersedianya piring atau mendengar langkah orang yang biasa memberi makan. Stimulus bersyarat ini nantinya akan memunculkan respon bersyarat atau Conditioned Response (CR).

Teori pengkondisian klasik dapat diterapkan dalam mencegah adiksi gadget yakni dengan membentuk sikap baik dalam individu anak, mengatur lingkungan yang nyaman bagi anak, membentuk kenyamanan di lingkungan bermain maupun lingkungan di dalam keluarga, serta dengan membiasakan perilaku secara kontinyu yang pada akhirnya dapat membentuk sebuah kebiasaan yang buahnya adalah berupa watak atau karakter. Karakter yang baik bermula dari pembiasaan pola perilaku yang baik, dan hal tersebut membutuhkan proses dengan memakan waktu yang relatif lama.

Secara garis besar, teori pembiasaan klasik yang digagas oleh Ivan Pavlov dapat digambarkan sebagai berikut.

\footnotetext{
36 Sumber: Google

${ }^{37}$ Santrock, J.W. Psikologi pendidikan. Jakarta: Kencana. (2013)

38 Slavin, R.E. Psikologi pendidikan teori dan praktik. Jakarta: PT Indeks. (2011)
}

113 | Jurnal Auladuna 


NS-------> NR
NS + UCS ---------> UCR
CS --------> CR
Keterangan:
NS : Neutral Stimulus
CS : Conditional Stimulus
UCS : Unconditional Stimulus
UCR : Unconditional Response
CR : Conditional Response

Berdasarkan skema tersebut, himbauan orangtua atau guru kepada anak untuk mengurangi penggunaan gadget. Ketika NS diberikan kepada anak, maka tidak ada respon yang muncul (tidak menunjukkan pengurangan penggunaan gadget oleh anak). Selanjutnya himbauan orangtua atau guru dalam pembatasan penggunaan gadget (NS) dikuatkan dengan pemberian reward, membentuk lingkungan yang nyaman, janji untuk mengajak rekreasi, atau berupa punishment (UCS), maka akan muncul perilaku pengurangan pemakaian gadget (UCR) pada anak. Ketika himbauan orangtua atau guru tentang pengurangan penggunaan gadget dibarengi dengan UCS dilakukan secara terus menerus, maka pengurangan penggunaan penggunaan gadget (UCR) dalam diri anak akan terbentuk. Pengurangan penggunaan gadget (CR) dapat diatasi dengan memberikan CS berupa pemberian reward, membentuk lingkungan yang nyaman, janji untuk mengajak rekreasi, atau berupa punishment. CS yang diberikan kepada anak secara kontinyu, maka akan membentuk sikap anak untuk membatasi dan mengurangi penggunaan gadget, bahkan dapat membentuk sikap anak untuk berhenti menggunakan gadget.

Membentuk lingkungan yang nyaman bagi siswa, entah lingkungan bermain atau hubungan kelekatan antara orangtua dengan anak akan membentuk stimulus dan memunculkan respon

pada anak. Sering mengajak anak untuk beraktivitas di luar ruangan juga terbukti mampu membatasi waktu bermain gadget pada anak. Pemberian reward juga mampu mengurangi penggunaan gadget pada anak. Apabila pengkondisian klasik ini dilakukan berkesinambungan, maka perilaku bahkan watak yang bagus dapat dibentuk dalam diri anak sejak dini.

\section{Membuat Perjanjian Antara Orangtua dengan Anak}

Menyepakai durasi bermain gadget dengan anak adalah hal yang ideal dilakukan untuk mencegah adiksi gadget pada anak. Orangtua dapat menerapkan kesepakatan dengan anak berapa lama dalam menggunakan gadget. Pilihan yang dapat diterapkan yakni mulai pembatasan selama setengah jam, 1 jam, hingga 2 jam. Apabila lebih dari dua jam maka orangtua wajib memberikan hukuman ataun punishment untuk mencegah perilaku candu dalam diri anak. Pembatasan penggunaan gadget pada harus disepakati dan dipatuhi bersama, sehingga menimbulkan kepercayaan baik bagi orangtua maupun bagi anak. Orangtua merasa dapat mengontrol anak dalam menggunakan gadget, sedangkan anak mematuhi perintah orangtua dengan melaksanakan pembatasan penggunaaan gadget. Pola kepatuhan anak terhadap orangtua juga akan terbentuk manakala hal ini dilakukan secara terus-menerus. Kebiasaan yang terbentuk menjadi sebuah perilaku akan Meningkatkan kualitas hidup anak dan tentu akan berdampak bagi prestasi akademik anak.

Teknis pelaksanaan penerapan perjanjian ini contohnya dengan memberitahukan anak ketika pukul 11.00 misalnya mulai menggunakan gadget, maka pukul 12.00 anak harus berhenti bermain gadget. Pola asuh seperti harus dilakukan setiap hari, kecuali hari libur. Pada hari libur orangtua bisa sedikit melonggarkan kesepakatan ini karena mengingat anak pasti membutuhkan 114 | Jurnal Auladuna 
Digital Parenting: Bagaimana Mencegah Kecanduan Gadget

liburan sehingga akses terhadap gadget sedikit diperpanjang namun harus sesuai koridor dan tidak berlebihan.

Selain itu, pada hari libur misalnya hari ahad, anak dapat diajak untuk bersepeda bersama orangtua, atau rekreasi ke suatu tempat untuk mengalihkan fokus anak dalam bermain gadget. Hal ini penting di samping untuk membentuk pola hubungan yang erat antara orangtua dengan anak, juga sedikit demi sedikit melupakan aktivitasnya dalam menggunakan gadget. Fisik dan mental anak juga berkembangan mengingat aktivitas di luar ruangan akan membuat pikiran anak fresh sebelum memulai aktivitas seperti biasa di hari senin.

\section{Memantau Aktivitas Browsing Anak Serta Membatasi Penggunaan Internet}

Setiap langkah preventif oleh orangtua maupun guru harus dilakukan dengan sungguhsungguh serta dengan kesabaran yang tinggi. Pada beberapa browser telah dilengkapi oleh pengembang aplikasi dengan menyematkan fitur-fitur tertentu agar anak tidak kecanduan gadget dan internet. Salah satu contohnya di browser Mozilla yang dapat membendung aksesibilitas website yang dapat dikunjungi oleh anak. Panduan untuk menggunakan fitur ini dapat diakses melalui website berikut https://support.mozilla.org/en-US/kb/block-and-unblock-websitespar ental-controls-firef. Mozilla sebagai salah satu browser yang populer mengembangkan fitur untuk memblok website yang tidak cocok dan tidak sesuai bagi anak serta membimbing orangtua atau guru untuk menerapkan pola asuh bagi anak di era digital. Pada saat orangtua menggunakan fitur ini, maka perilaku anak dalam menggunakan gadget dan internet dapat terkontrol dan diamati oleh orangtua. Selain menggunakan fitur block, orangtua juga dapat memantau riwayat website yang diakses oleh anak selama menggunakan internet.

Selain menggunakan menu block and unblock, para orangtua juga disarankan untuk memasang beberapa add-ons di browser Mozilla untuk

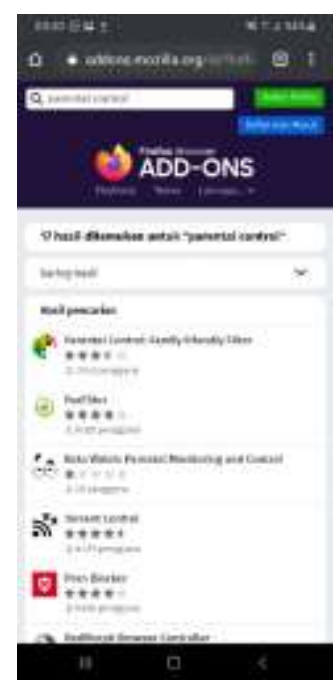

Gambar 3. Add-ons pada browser Mozilla Firefo $x^{39}$

meningkatkan pola asuh di era digital. Add-ons adalah pengaya yang disedaikan oleh Mozilla Firefox untuk kinerja tambahan bagi pengoperasian pada saat menjalanakn aplikasi. Add-ons yang tersedia pada browser Mozilla Firefox seperti ditampilkan pada gambar 3. Pada gambar ada beberapa add-ons yang tersedia seperti parental control, foxfilter, beta watch, torrent control, porn blocker,

${ }^{39}$ Dokumen penulis

115 | Jurnal Auladuna 
dan lain-lain. Beberapa add-ons tersebut dapat dimanfaatkan oleh orangtua untuk diinstal di gadget.

\section{Menggunakan Fitur Screen Time}

Screen time adalah sebuah istilah yang disematkan ketika seseorang menggunakan gadget dengan durasi tertentu. Fitur screen time memungkinkan orangtua untuk membatasi anak dalam menggunakan gadget. Pembatasan ini dapat diketahui dengan hasil yang dilampirkan di layar menu utama sebuah gadget atau smartphone. Dalam lampiran di menu utama, ditampilkan hasil rekapan screen time sebuah gadget selama satu minggu. Berikut ini adalah contoh fitur screen time di iPhone $5 \mathrm{~s}$.

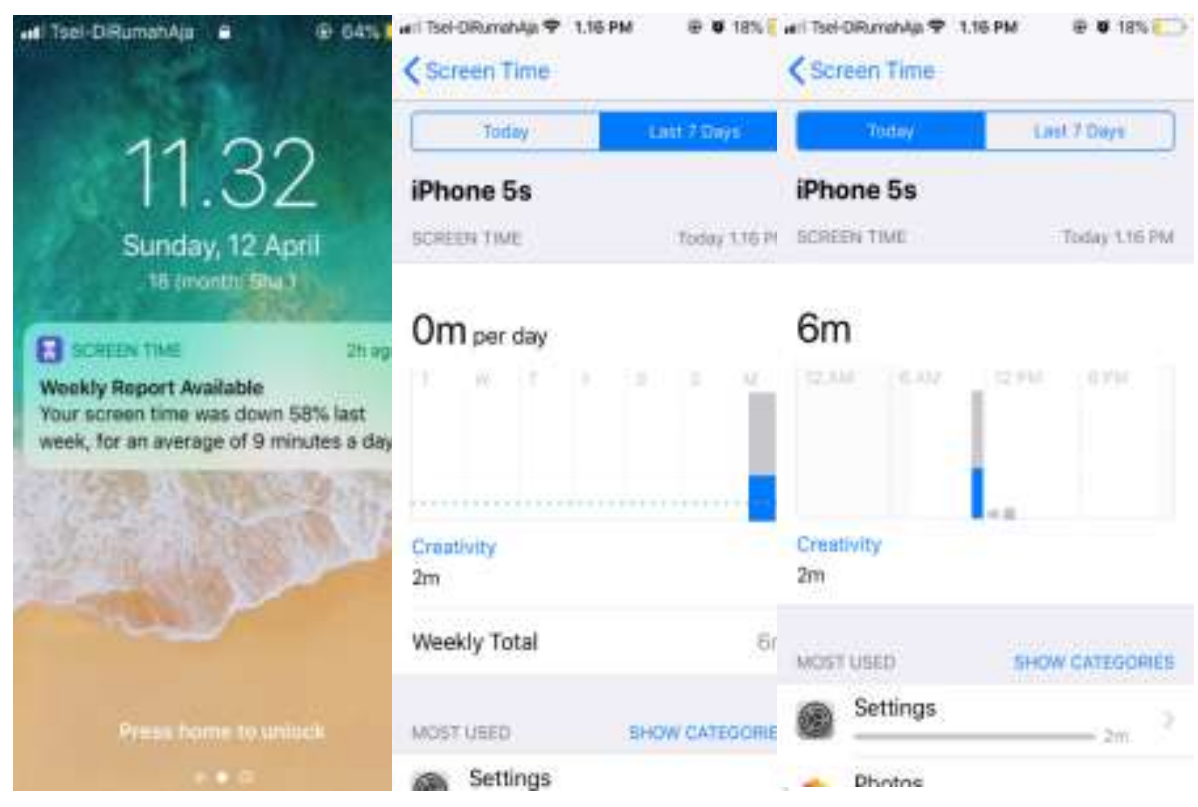

Gambar 4. Screen time pada sistem operasi $\operatorname{iOS}^{40}$

Pada gambar 4 tersebut ditampilkan bahwa screen time selama satu minggu menurun 58\% dibandingkan dengan minggu yang lalu dengan rata-rata penggunaan gadget sebesar 9 menit per hari. Di dalam satu hari ditampilkan berapa durasi yang dihabiskan selama mengakses gadget, dan rata-rata per munggu.

Pada sistem operasi android juga disediakan fitur screen time untuk mengontrol penggunanya dalam menggunakan gadget. Di dalamnya juga disematkan beberapa fitur tambahan yang dikategorikan ke dalam fitur family care atau fitur yang memungkinkan pengguna mengontrol anak-anak dalam menggunakan gadget. Fitur screen time dalam sistem operasi android di kategorikan ke dalam fitur family care.

Memaksimalkan fitur yang ada di dalam sistem operasi selain berdampak kepada perkembangan anak, juga dapat menjadi bahan evaluasi bagi para developer untuk mengembangkan aplikasi yang lebih bermanfaat serta bagi para perusahaan besar teknologi seperti Google, Apple, Microsoft, Huawei, dan lain-lain.

40 Ibid

116 | Jurnal Auladuna 


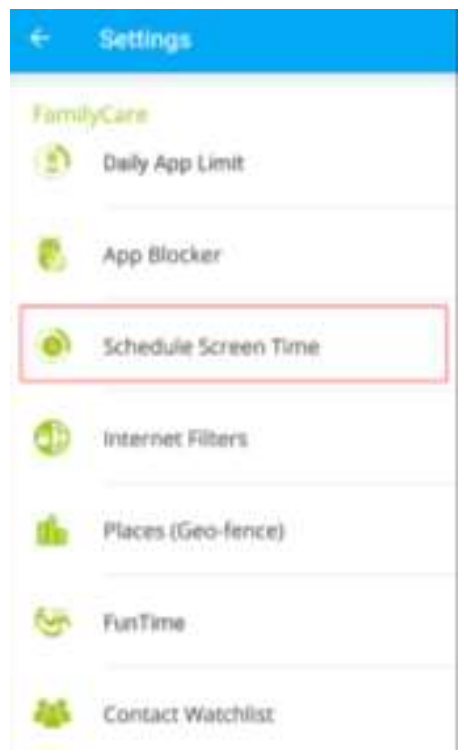

Gambar 5. Screen time pada sistem operasi Android ${ }^{41}$

\section{Penggunaan beberapa aplikasi}

Di abad ke 21 ini, dunia internet semakin berkembang tanpa mampu dibendung. Ekspansi dan tingkat adopsi yang tinggi membuat semua orang di lintas usia bahkan wilayah di seluruh Indonesia mampu mengakses internet tanpa harus berjuang mati-matian untuk mendapatkannya. Pemerintah melalui Kementerian Komunikasi dan Informatika telah meluncurkan pogram Tol Langit dan Palapa Ring, yang notabene keduanya merupakan upaya untuk menguatkan infrastruktur di bidang telekomunikasi dan informatika termasuk internet. Jangkauan beberapa operator jaringan hingga ke pelosok negeri merupakan upaya maksimal untuk meratakan dan menyebarluaskan jangkauan sinyal agar warga atau masyarakat yang ada di daerah pelosok dapat menikmati kemudahan mengakses internet. Namun siapa sangka, menurut beberapa ahli serta beberapa kajian menyebutkan bahwa internet seperti dua mata pisau, dimana satu sisi memiliki sisi positif namun di sisi lainnya ada sisi negatif yang terus mengintai penggunanya.

Para pengembang aplikasi yang bermarkas di Amerika Serikat, seperti Google, Apple, dan Microsoft mengembangkan beberapa aplikasi dan mengupayakan beberapa langkah agar pengguna internet terhindar dari kecanduan gadget. Hal ini penting karena kecanduan gadget tidak hanya berpengaruh bagi kesehatan fisik seseorang akan tetapu juga berpengaruh terhadap kesehatan mental seseorang. Para psikolog dan praktisi pendidikan mendorong para pengembang aplikasi untuk peduli terhadap pengguna internet yang masih dalam rentang usia anak-anak. Oleh sebab itu, pada beberapa aplikasi berikut telah disematkan fitur untuk mengontrol penggunaan internet oleh anak, sehingga dapat dikontrol oleh orangtua maupun guru.

\section{a. Youtube Kids}

Youtube kids adalah platform untuk mengakses video berbasis internet yang diperuntukkan pada anak usia sekolah dasar. Youtubekids menyediakan ribuan bahka

${ }^{41}$ Ibid

117 | Jurnal Auladuna 
jutaan video yang diupload oleh para youtuber atau pengembang video lainnya dari seluruh dunia. Youtube kids adalah platform untuk anak mengeksplore diri sendiri dan lingkungan sekitar guna mengembangkan hard skill maupun soft skill dalam diri anak. Youtube kids selain dijadikan sebagai ruangan untuk kreativitas anak, tetapi juga sebagai wadah untuk aktualisasi diri anak dalam mengenal dunia luar terutama di era digital seperti saat ini.

Kebijakan yang dikeluarkan oleh Google selaku perusahaan yang memiliki Youtube Kids tentu berbeda dengan aplikasi Youtube pada umumnya. Salah satu yang menjadi syarat saat menginstal aplikasi ini

Gambar 6. Aplikasi youtube kids pada sistem operasi android ${ }^{42}$

adalah rentang usia pengguna yakni di kisaran usia 1-13 tahun atau usia sekolah dasar. Meskipun demikian, orangtua harus tetap mengontrol dan mengawasi pemakaian Youtube Kids agar akses anak terhadap gadget dan internet dapat dibatasi.

Aplikasi Youtube Kids dapat diperoleh di App Store untuk sistem operasi iOS serta di Play Store untuk sistem operasi Andorid. Berikut ini ditampilkan screenshot dari aplikasi Youtube Kids.

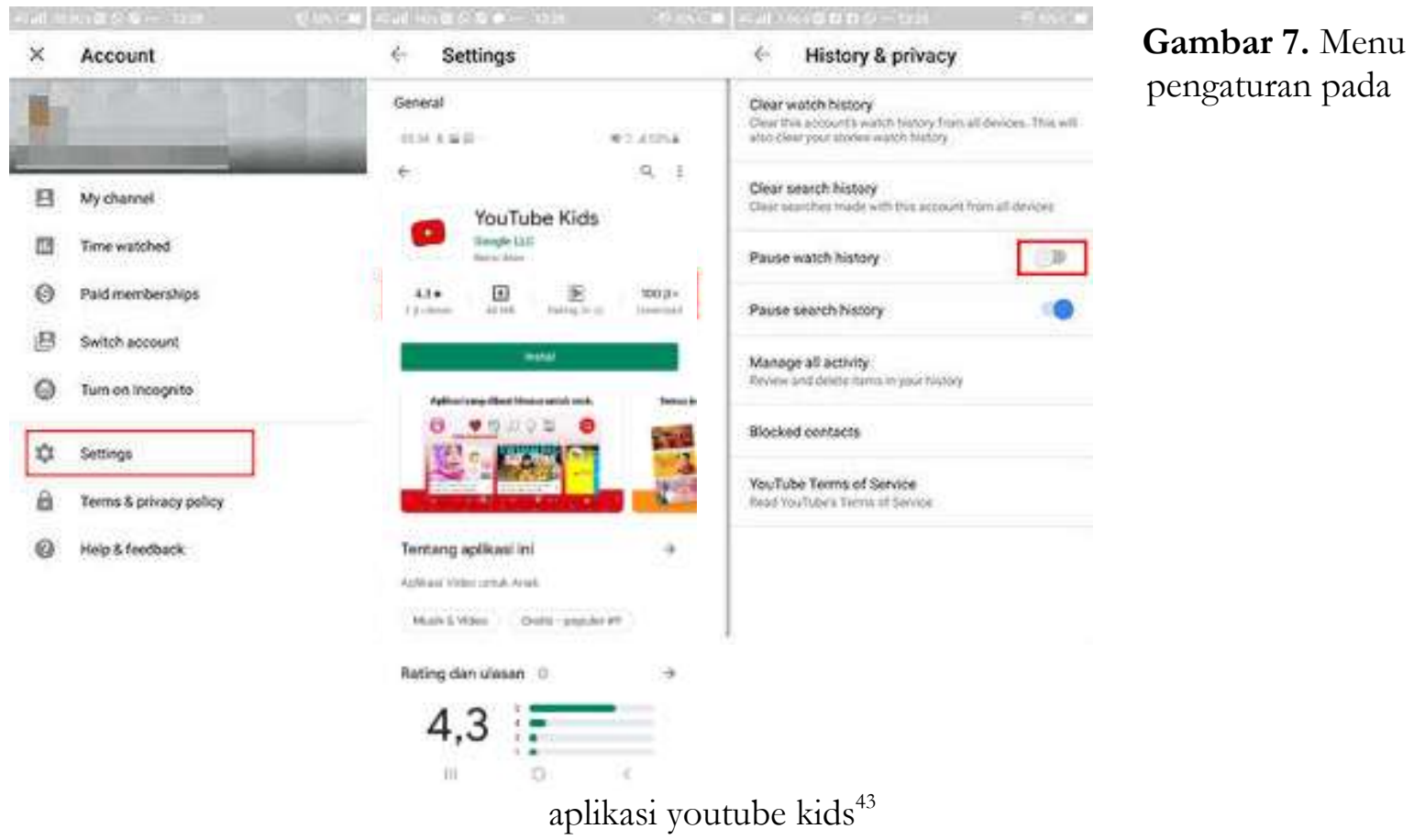

Pada menu setting dan privacy para orangtua disediakan beberapa pilihan untuk membatasi akses anak terhadap gadget yang terhubung melalui internet.

\section{b. Apple Education}

Apple education adalah program yang digagas oleh Apple Inc. yang bergerak dalam bidang pendidikan. Program ini menyasar negara-negara berkembang seperti Afrika, dan Asia Tenggara seperti Indonesia untuk membantu siswa dalam mengakses dunia

42 Ibid

${ }^{43}$ Google

118 | Jurnal Auladuna 
Digital Parenting: Bagaimana Mencegah Kecanduan Gadget

pendidikan. Sasaran program ini adalah daerah-daearh yang sulit terjangkau oleh internet, serta sumber daya yang minim.

Apple for Education juga merupakan program yang berupaya memanfaatkan teknologi sebagai media pembelajaran, sehingga dapat mengurangi adiksi terhadap gadget karena terlalu lama mengaksesnya. Membelokkan keinginan anak terhadap gadget adalah salah satu langkah yang ditempuh oleh Apple untuk membuat sarana teknologi menjadi lebih bermanfaat Layanan apple for education ini dapat diakses melalui laman: https://apple.com/education/k12/. Berikut ditampilkan screenshot dari program Appel for Education terutama untuk K-12 education (diperuntukkan pada siswa sekolah).

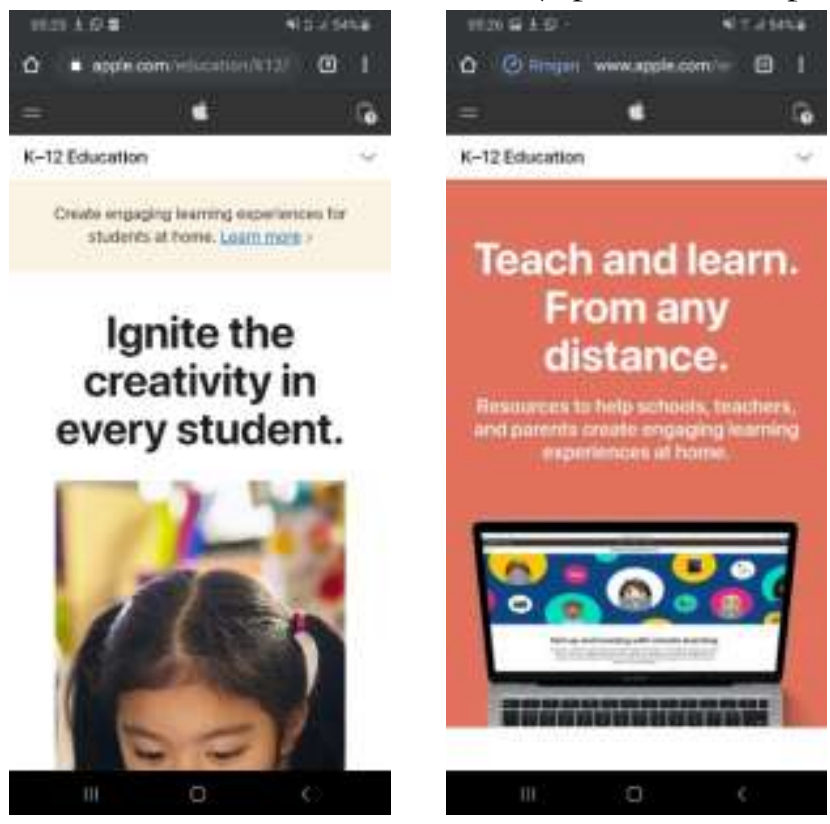

Gambar 8. Layanan Apple for education (K-12 Education) ${ }^{44}$

\section{c. Microsoft Education Center}

Mirip dengan Apple for education, Microsoft salah satu raksasa dalam bidang teknologi juga mengembangkan program yang bergerak dalam bidang pendidikan. Di dalam menu Microsoft for education terdapat education center yang berisi tentang program distance learning yang memungkinkan pengguna atau siswa belajar dari jarak jauh. Fitur ini dapat dimanfaatkan manakal terjadi pandemi virus corona seperti saat ini sehingga mengharuskan siswa untuk LFH (learning from home).

Layanan Microsoft Education dapat diakses melalui laman: https://education.microsoft.com/en-us. Gambar 9 berikut ini merupakan hasil screenshot layanan Microsoft Education.

${ }^{44}$ Dokumen pribadi 119 | Jurnal Auladuna 


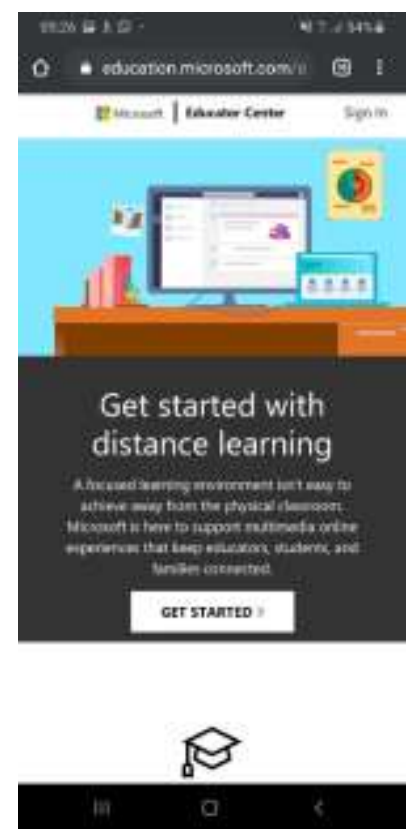

Gambar 9. Layanan Apple for education (K-12 Education) ${ }^{45}$

\section{d. Google Classroom}

Google classroom adalah platform yang dikembangkan oleh google dalam rangka berkontribusi di bidang pendidikan. Google mengembangkan classroom untuk menunjang pembelajaran jarak jauh, terutama pada masa pandemi corona di tahun 2020. Layanan google classroom dapat dinikmati dengan login dengan akun google lalu mengakses di laman: https://classroom.google.com atau mengunduh di Play Store bagi platform android dan di App Store bagi platform iOS.

Google bekerjasama dengan guru di seluruh negeri untuk berkolaborasi dalam menciptakan iklim pembelajaran. Dengan beberapa fitur yang efisien, mudah digunakan, dan membantu guru dalam mengelola tugas membuat fitur ini populer akhir-akhir ini di tengah pandemi virus corona.

Fasilitas berupa penyimpanan di google drive serta terintegrasi dengan google sutie, google classroom menyederhanakan tugas yang berulang membantu para guru untuk lebih berfokus pada tugas terpetingnya yaitu mengajar. Fitur ini dikembangkan untuk dapat diakses oleh guru dan siswa di seluruh dunia secara gratis.

Melalui google classroom, guru dan siswa dapat melaksanakan pembelajaran dimanapun dan kapanpun. Guru juga dapat melacak progres siswa untuk mengetahui dimana dan kapan harus memberikan evaluasi dan relfeksi setelah proses pembelajaran berlangsung. 
Digital Parenting: Bagaimana Mencegah Kecanduan Gadget...........

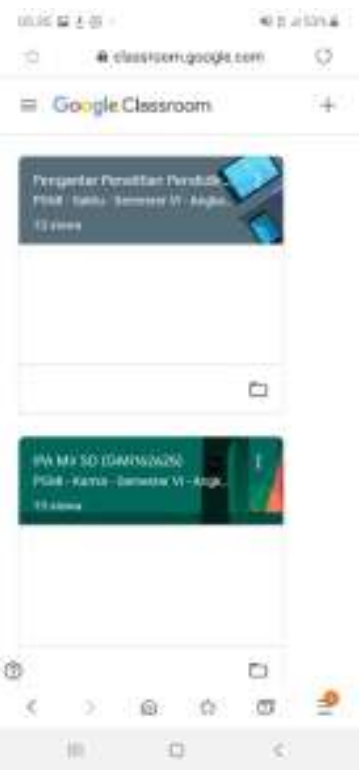

Gambar 10. Tampilan google classroom

Google classroom juga memberikan ruang (space) bagi guru dan orangtua untuk saling memantau aktivitas anak menggunakan gadget, sehingga adiksi gadget dalam diri anak dapat berangsur-angsur berkurang. Memanfaatkan teknologi informasi untuk pembentukan sikap dan perilaku anak adalah langkah yang paling awal dalam upaya pembentukan karakter serta turut serta dalam menciptakan iklim pembelajaran yang menyenangkan dan mampu dijangkau oleh seluruh siswa yang ada di Indonesia.

\section{Kesimpulan}

Adiksi gadget yang semakin mengkhawatirkan membuat pemerintah, guru, dan orangtua harus mampu menemukan solusi jitu dalam mengatasi maupun mencegahnya. Upaya nyata dan solutif haruslah dilakukan secara terus-menerus guna membatasi perilaku anak dalam mengakses gadget. Orangtua dan guru haruslah bekerjasama dalam mengawasi anak terutama dalam menggunakan internet. Apa yang diakses, apa yang dilakukan selama menggunakan gadget, serta apa dampak yang timbul setelah menggunakan gadget haruslah menjadi bahan evaluasi bagi pemerintah, guru, dan orangtua supaya di waktu yang akan datang dapat dilahirkan sebuah formula atau sistem yang dapat mengatur perilaku siswa dalam mengakses gadget namun mampu menghindarkan pengguna dari kecanduan.

\section{Daftar Pustaka}

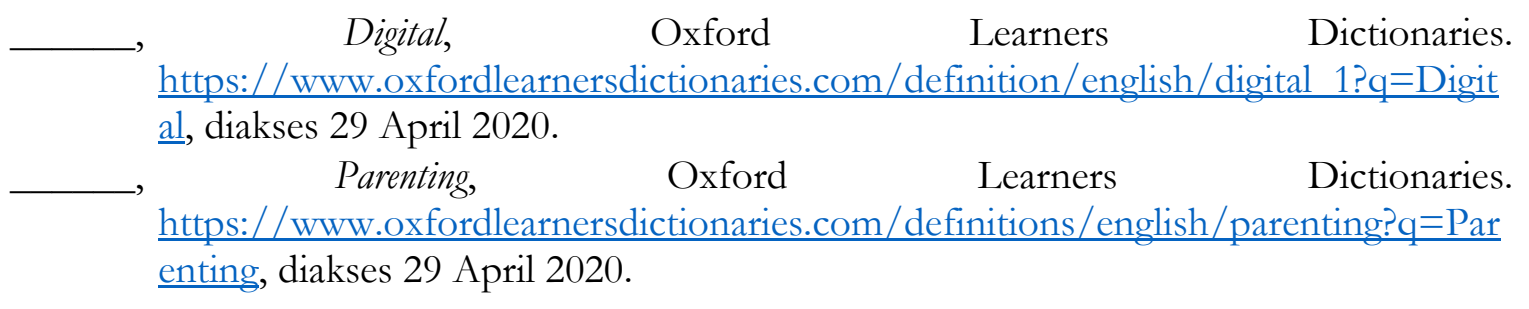

121 | Jurnal Auladuna 
Álvarez, M., Torres, A., Rodríguez, E., Padilla, S., Rodrigo, J. M. Attitudes and parenting dimensions in parents' regulation of Internet use by primary and secondary school children. Computer \& Education. 67, 69-78. doi:10.1016/j.compedu.2013.03.005, 2013.

Ante-Contreras, D. (2016). Distracted parenting: How social media affects parent-child attachment (Unpublished master's thesis). San Bernardino, CA: California State University. Diakses dari: http://scholarworks.lib.csusb.edu/cgi/viewcontent.cgi?article $1 / 41338 \&$ context $1 / 4$ etd

Blackman, A. Screen time for parents and caregivers: Parental screen distraction and parenting perceptions and beliefs (Unpublished doctoral dissertation). New York, NY: Pace University, 2015.

Bloomfield, L., \& Kendall, S. Parenting self-efficacy, parenting stress and child behavior before and after a parenting programme. Primary health care research \& development, 13, 364-372. doi:10.1017/S1463423612000060, 2012.

Bornstein, M. H. Determinants of parenting. Developmental Psychopathology, Third Edition, John Wiley \& Sons. Diakses dari: http://twin.scihub.tw/c0c1122e2fee7e3e589325e1e08e869a/ bornstein2016.pdf, 2016.

Center on Media and Human Development. Parenting in the age of digital technology: A national survey (revised). School of Communication, Northwestern University. Diakses dari: http://cmhd.northwestern.edu/wp-content/uploads/2015/ 06/ParentingAgeDigitalTechnology.REVISED.FINAL .2014.pdf, 2014.

Cole, P. M., LeDonne, E. N., \& Tan, P. Z. A longitudinal examination of maternal emotions in relation to young children's developing self-regulation. Parenting, 13(2), 113-132. doi:10.1080/15295192.2012.7091 52, 2013.

Dale H. Schunk. Learning Theories. Pustaka Pelajar: Yogyakarta, 2012.

Denham, S. A. Maternal emotional responsiveness and toddlers' social-emotional competence. Journal of Child Psychology and Psychiatry, 34(5), 715-728. doi:10.1111/j.14697610.1993.tb01066.x, 1993.

Fay-Stammbach, T., Hawes, D. J., \& Meredith, P. Parenting influences on executive function in early childhood: A review. Child Development Perspectives, 8(4), 258-264. doi:10.1111/cdep.12095, 2014.

Golen, R. B., \& Ventura, A. K. Mindless feeding. Is maternal distraction during bottle-feeding associated with overfeeding? Appetite, 91, 385-392. doi:10.1016/j.appet.2015.04.078, 2015.

Hajal, N. J., Cole, P. M., \& Teti, D. M. Maternal responses to infant distress: linkages between specific emotions and neurophysiological processes. Parenting, 17(3), 200-224. doi:10.1080/15295192.2017.13360 01, 2017.

Hendriyani, Hollander, E., d'Haenes, L., Beentjes, J. Views on children's media use in Indonesia: Parents, children, and teachers. International Communication Gazette. 76(4-5), 322-339. doi:10.1177/1748048514523527, 2014.

Hiniker, A., Schoenebeck, S. Y., \& Kientz, J. A. Not at the dinner table: Parents' and children's perspectives on family technology rules. In Proceedings of the19th ACM conference on computer-supported cooperative work \& social computing (pp. 1376-1389). doi:10.1145/281804.28199940, 2016.

Huang, K.-Y., Teti, D. M., Caughy, M. O., Feldstein, S., \& Genevro, J. Mother-child conflict interaction in the toddler years: Behavior patterns and correlates. Journal of Child and Family Studies, 16(2), 219-241. doi:10.1007/s10826-006-9081-6, 2007.

122 | Jurnal Auladuna 
Digital Parenting: Bagaimana Mencegah Kecanduan Gadget..

Kildare, C. A., \& Middlemiss, W. Impact of parents mobile device use on parent-child interaction: A literature review. Computers in Human Behavior, 75(2017), 579-593. doi:10.1016/j.chb.2017.06.003, 2017.

Krueger, A., Kahneman, D., Schkade, D., Schwarz, N., \& Stone, A. National time accounting: The currency of life. In A. Krueger (Ed.), National time accounting and subjective well-being (pp. 9-84). Chicago, IL: University of Chicago Press. Retrieved from: $\quad \underline{\text { https://dornsife.usc.edu/assets/sites/780/docs/09 ch }}$ krueger et al national time accounting nber proofs.pdf, 2009.

Kushlev, K. Digitally connected, socially disconnected: Can smartphones compromise the benefits of interacting with others? (Unpublished doctoral dissertation). Vancouver, Canada: The University of British Columbia. Diakses dari: https://open.library.ubc.ca /cIRcle/collections/ubctheses/24/items/1.0166492, 2015.

Livingstone S, Haddon L, Görzig A, et al. (2011). EU kids online final report. LSE, London: EU Kids Online. Diakses dari: http://www.lse.ac.uk/media\%40lse/ research/EUKidsOnline/EU\%20Kids\%20II\%20(2009-11)/EUKidsOnlineIIRepo rts/Final\%20report.pdf, 2011.

Livingstone, S., \& Haddon, L. EU kids online: Final report. LSE, London: EU Kids Online. Diakses_dari: http://www.lse.ac.uk/media@lse/research/EUKids Online/EU\%20Kids\%20I\%20(2006-9)/EU\%20Kids $\%$ 20Online\%20I\%20Reports/EUKidsOnlineFinalReport.pdf, 2009.

Martin, S. E., Clements, M. L., \& Crnic, K. A. Maternal emotions during mother-toddler interaction: parenting in affective context. Parenting, 2(2), 105-126. doi:10.1207/S15327922PAR0202_02, 2002.

McDaniel, B. T., \& Coyne, S. M. Technology interference in the parenting of young children: Implications for mothers' perceptions of coparenting. The Social Science Journal, 53(4), 435e443. doi:10.1016/j.soscij.2016.04.010, 2016.

Measelle, R. J., \& Ablow C. J. Contributions of early adversity to pro-inflammatory phenotype in infancy: the buffer provided by attachment security. Attachment \& Human Development, doi:10.1080/14616734.2017.1362657, 2017.

Moser, C., Schoenebeck, S. Y., \& Reinecke, K. Technology at the table: Attitudes about mobile phone use at mealtimes. In Proceedings of the 2016 conference on human factors in computer systems (pp. 1881-1892). doi:10.1145/2858036.2858357, 2016.

Oduor, E., Neustaedter, C., Odom, W., Tang, A., Moallem, N., Tory, M., et al. The frustrations and benefits of mobile device usage in the home when co-present with family members. In Proceedings of the annual designing interactive systems conference (pp. 1-13). doi:10.1145/2901790.2901809, 2016.

Radesky, J. S., Kistin, C. J., Zuckerman, B., Nitzberg, K., Gross, J., Kaplan-Sanoff, M., et al. Patterns of mobile device use by caregivers and cbildren during meals in fast food restaurants. Pediatrics, 133(4), e843e-e850. doi:10.1542/peds. 2013-3703, 2014.

Radesky, J., Miller, A. L., Rosenblum, K. L., Appugliese, D., Kaciroti, N., \& Lumeng, J. C. Maternal mobile device use during a structured parent child interaction task. Academic Pediatrics, 15(2), 238-244. doi:10.1016/j.acap.2014. 10.001, 2014.

Santrock, JW. Psikologi pendidikan. Jakarta: Kencana, 2013.

Slavin, RE. Psikologi pendidikan teori dan praktik. Jakarta: PT Indeks, 2011.

123 | Jurnal Auladuna 